\title{
Pipeline Transportation of Solid Materials
}

\author{
Ewa Kulińska \\ Opole University of Technology, Opole, Poland
}

\begin{abstract}
The reasons behind the search for alternatives to the currently used transport methods are congestions in communication systems, roads, stations, and transport nodes, which were built years ago and are not able to handle with the current load, the increasing number of motor vehicles, the emergence of congestions in the road network and disruptions reducing smooth traffic flow. The consequence of the phenomena is the transport congestion in urban transport systems. This article describes possibilities to change this state of affairs with the use of alternative transport method, which is the underground pipeline transportation of solid and bulk goods. The main objective of the study is to indicate the possible ways of using alternative transport routes to reduce transport congestion in large urban areas and industrial areas. There are currently implemented at least three research projects aiming to develop the theoretical and practical foundations for the underground transport of solid materials by using pipelines. In 2008, at the University of Oxford, research project Fri. FOODTUBES тм was launched. At the Ruhr University in Bochum, the project Cargo Cap is in realization. A new initiative (2014) is a research project carried out by a group of Captrans universities from the Czech Republic, Slovakia, Poland, Italy, and Greece. Methodology used in those projects is primarily an analysis of reports on the current and projected traffic on the roads, highways, major hubs ect.; analysis of technical solutions used in pipeline transport of liquids and gas, as well as underground corridors drilling technologies for sewage pipes for various purposes. In the projects, there are also used computer simulations and prototypes are built. Developing parameters for the safe transport of solids in pipes is not an easy task. The solution must take into consideration logistics, economic, ecological, geological, legal, and many other aspects.
\end{abstract}

Keywords: pipeline transportation, solid and bulk materials, congestions, communication systems

\section{Introduction}

Economic development directly affects the traffic load of the existing road infrastructure. It is caused by the increase in flows of goods and passengers. Consequently, problems and limitations appear in shaping flexible delivery times and the effectiveness of their execution by logistics service providers decreases.

The pipeline transportation is one of the five transport systems next to the road, rail, air, and water transport. Pipelines provide an opportunity for safe and cost-effective transportation that can be already seen in the case of liquid or gas materials or transporting people in the underground. In crowded urban areas, it is a great alternative for transport of solid materials as it is a fast and eco-friendly one. Now, the time has come to

Ewa Kulińska, associate professor, Head of Department of Logistics, Institute of Industrial Processes Generating Capacity, Faculty of Production Engineering and Logistics, Opole University of Technology, Opole, Poland.

Correspondence concerning this article should be addressed to Ewa Kulińska, Ozimska 75 Street, 45-370 Opole, Poland. E-mail: e.kulinska@po.opole.pl. 
run the streams of goods, which are causing congestions on our roads, using alternative paths. It is the time to develop a pipeline network, which could be used to transport refrigerators, washing machines, car parts, cereals, food products, and other articles of daily use.

A group of academics is proposing a system of underground tunnels which could deliver food and other goods in all weather conditions with massive energy savings. They want to put goods in capsules, which are shifted through underground tubes, directed by linear induction motors, and routed by intelligent software to their destinations.

The object of the article is to point out possible ways of using an alternative transport route in order to reduce transport congestion in large urban areas and industrial areas. Underground transport is still in the concept stage, so the aim of the projects is to design and to build an energy saving pipeline for capsuled goods transportation system.

At present $92 \%$ of the energy used to transport food and other supermarket goods are spent on moving the vehicles with only $8 \%$ used to move the goods. The project's aim is to replace heavy goods-transporting vehicles with lightweight carbon fibre freight cargo capsules, each two metres in length, running in underground pipelines, and directly linking food processing and production centres with shop loading bays. The total volume of food transported in the UK in a year could be accommodated in a system consisting of 20,000 kilometres of one metre diameter pipeline and 3.5 million solid material transportation capsules.

The replacement of food road transport with food pipelines in the UK could save billions of litres of fuel per year, preserve the countryside, reduce street level pollution and global warming gases, and free up congested roads.

The capsules will be computer-controlled. Pipeline building costs will be more than recouped through reduced road building and maintenance as tubes can be buried for long distances and take shorter and more direct routes to distribution hubs and customers' terminals.

So far it is known that scientists from the project FOODTUBES in 2008, the team, comprising 20 world class scientists and engineers, have been invited to present commercial transport applications for London, Buenos Aries, and the University of Texas.

\section{Literature Review}

The literature concerning all aspects of the implementation of the underground transport of solids is very modest yet.

There are studies dealing with problem of underground transport of people, describing the construction and transport organization in the underground. Many publications describe the constructing, fracturing pipelines for transportation of liquids and gases.

Among the first publications on the underground transport of solids is an article by Roe (1998) - the Use of Pipelines for the Urban Distribution of Goods. The article Classics in Transportation Analysis: Transport Logistics written by McKinnon, Button, and Nijkamp (2003), is where you can find the preliminary concepts for underground transport.

Sources of information on this topic for now can be found on the websites of individual projects and in publications of their leaders. Most of the information presented by journalists or researchers and interested in this subject come from these websites, including the BBC and New Scientist. 


\section{Current State of Research}

The reasons behind the search of alternatives to the current ways of transportation are intuitive. Congestions of communication systems are already the problem not only to large cities or metropolitan areas but also occurring in smaller urban centers. Roads, stations, and communication nodes, which were built years ago, are not able to handle the traffic load. The communication progress results in a growing number of motor vehicles, in emergence of traffic congestion in the road network and in interferences reducing traffic smoothness. The consequence of the phenomena is the transport congestion in urban transport systems (Kulińska, Rut, \& Partyka, 2014). It is understood here as a traffic overload, congestions on communication routes, traffic hold-up, and redundancy (Wappa \& Halicka, 2011).

The road transport has reached its limits in terms of capacity. While studying current problems, the information can be found that $10 \%$ of the $11,000 \mathrm{~km}$ of German motorways turns into a "parking" every day (Hölzel, 2014).

At the very moment, the costs of this problem are estimated for about 100 billion euros per year and the problem is getting bigger every year. By 2020, the road traffic is supposed to be doubled compared to 1997 .

The growing importance of the inter-organization division of labor and the Europeanization of the economy cause that the road transport of goods is becoming an increasing risk factor for companies. The delivery time of goods or materials for production starts to be more and more difficult to determine (Hölzel, 2014).

Ecological consequences are also an important issue related to the increasing road transport, such as: huge mineral oil consumption; noise, not only on motorways, but also in towns; pollution; accidents, and a significant demand for land (converting agricultural into commercial land).

There is, however, a possibility to reduce the road traffic and route the streams of goods using an alternative path. Water, gas, electricity, and central heating are transported under the ground in towns-why not send solid goods in this way?

Currently, the pipeline transportation is defined as transport of goods through pipelines, such as transportation of crude oil and related products, water and gas (Official Journal of the European Union, 2014) - it is the highest time to extend this definition.

\section{Research Problems to Be Solved}

The reasons behind the search of alternatives to the current ways of transportation are intuitive. Congestions of communication systems are already a problem not only to large cities or metropolitan areas but also occurring in smaller urban centers.

There are already several initiatives and research projects, which are aimed at development of theoretical and practical foundations for underground transportation of solid materials using pipelines.

It was in 2008 that the research project FOODTUBES TM was launched at the Oxford University under the direction of Noel Hodson. The aim of the FOODTUBES тм project is to design and build energy-efficient capsules for transportation of food products. The Cargo Cap is a project with similar assumptions being executed at the Bochum Ruhr University under the direction of Professor Dietrich Stein. The research is supported by the German Ministry of Innovation, Science, Research, and Technology of North Rhine-Westphalia. Another project is conducted in the United States. A new initiative (year 2014) is the 
Captrans research project executed within the framework of the Horizon 2020 by the Czech Technical University in Prague, the Higher School of Logistics in Przerowa, the Technical University in Kosice, AF-CITYPLAN $^{1}$ in Prague, the Technical University of Opole, ESB (Energie-stavební a báňská) ${ }^{2}$, ITL (Institute for Transport and Logistics from Italy), and PPA (Piraeus Port Authority from Greece).

Approaches of researchers to design a pipeline network for transport of solids are different, however, there can be distinguished research problems, which appear in each of them, such as geological studies and determination of tunneling possibilities in the areas, where the network is supposed to be constructed. The issue of designing appropriate containers and equipment for handling terminals has to be solved. The development of the container shape, which will consequently determine the pipeline profile and container space of terminals, is also crucial. These are the issues related to the development of the container drive that belongs also to significant problems to be solved. Moreover, these are the issues related to the construction of terminals and other facilities needed to support the pipeline network and the development of the information system for communication amongst users, customers, records of containers in terminals, sorting by destination and automation of all routes that have to be solved as well. On this basis, eight main research areas can be distinguished:

(1) the development of pipeline routes: Which of the most populated and industrialized areas should be taken into account, while creating the pipeline network map; where the transmit stations should be located; how harbors, railway stations, airports, and logistics centers should be connected with the pipeline network; should be the entire pipeline constructed underground or should it have over ground parts;

(2) the development of the capsule construction: selection of criteria for the capsule shape, selection of the material, what failures may occur and how to solve them in practice;

(3) technical problems: What kind of a drive should be chosen for the capsules; should it be a drive in the pipeline, what should be the cross-section of the pipeline (round or other), how many capsules should be in one section (one or more), what should be the length of the pipeline sections-from a station to a station;

(4) the cross-section and the construction of pipeline routes: the way of tunneling; what material should be used for the construction; identification of grounds, in which the pipelines are supposed to be built; assessment of tunneling possibilities, criteria for the selection of routes according to geological obstacles, land ownership and security;

(5) control: monitoring of a capsule, container identification, information security, a simulator of capsule and pipeline operations, pipeline segmentation;

(6) reliability: pipeline safety, immediate removal of breakdowns, signaling breakdowns, transport conditions for hazardous and flammable materials, etc.; the possibility of using the pipeline in case of war, contingencies, riots in some parts of Europe or the world;

(7) legal problems;

(8) the risk analysis of the project-economic analysis in terms of the active environment protection, environmental and social analysis.

\footnotetext{
${ }^{1}$ AF-CITYPLAN is a modern engineering company focusing on infrastructure development of cities and regions. The scope of our activities stretches over the river of the unknown and risky environment, over which people are building paths for investments of our customers - from research and development to implementation projects and construction management.

2 The company Energie-stavební a báňská is Czech construction company with the capital of CZK 235 million, 500 of non-contingent workers and current annual turnover CZK 1.9 billion. The company has been operating on the Czech construction market for over 50 years.
} 


\section{Concepts and Proposals of Solutions}

\section{Outlining Pipeline Routes}

The largest demand for this form of transportation exists in the heavily urbanized areas, within large urban and industrial agglomerations. The significant number of the population at such places resulting in the increased transport needs to provide goods satisfying daily needs. Satisfying the needs by the supplying part depends on the quality of logistics services to a large extent. In particular, small deliveries to individual customers are considered here. Due to bottlenecks and expansive urban development plans, despite the extensive needs, there is no way to extend/enlarge the existing road network. The demand needs and consequently supply needs to offer quality transport services require introduction of alternative means of transport.

According to the researchers developing the concept of the pipeline transportation of solid materials of the Foodtubes and Cago Cap projects, this type of transport is particularly suitable for food, consumption, and investment goods, such as production components. It is estimated that this solution can be used for two-thirds of goods being transported by road.

According to the report of Colliers International (Retrieved from http://spedycje.pl/logistyka/centra_logistyczne/28612/do_2020_r_polska_centrum_logistycznym_europy.html), the market of logistics and industrial space will gradually grow in Europe over the next 10 years and the countries with the greatest potential are Poland and Turkey.

The Colliers report lists the following towns as the fastest growing distribution centers until 2020: Gdansk/Gdynia; Lodz, Katowice/Wroclaw; Bratislava (Slovakia)/Brno (Czech Republic), Izmir (Turkey); Belgrade/Nis (Serbia); Istanbul (Turkey), Moscow (Russia), and St. Petersburg (Russia), which will become the main logistics centers (Figure 1).

Pipeline network planning should take into account logistics centers located in Poland and throughout Europe. The existing road network can be used, under which the pipeline could be constructed. Moreover, the pipeline network could take into account strategic production/manufacturing industries such as cement plants, granaries, or factories producing various bulk and solid materials. Underground pipelines should be built in strategic areas, which are important elements of the European logistic infrastructure. Here among others are seaports, river ports, railway stations, and airports.
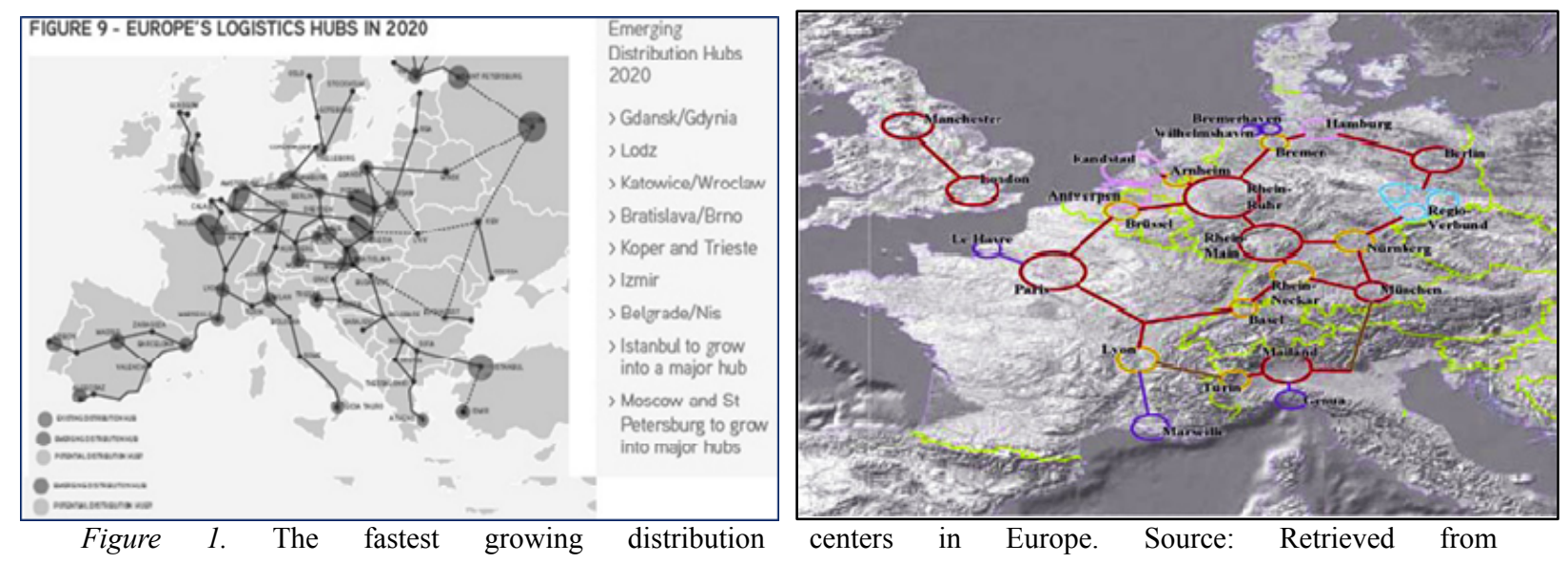

http://spedycje.pl/logistyka/centra_logistyczne/28612/do_2020_r_polska_centrum_logistycznym_europy.html. 
The management of transport routs must be fine-tuned and very well-synchronized in time. The already existing solutions, which are used to manage underground public transport such as subway, can be used for this purpose. However, the existing solutions used in subways would have to be adopted for the needs and requirements of underground pipelines for goods and materials. It is also important to take into account relevant safety and risk aspects arising, for example, from various types of failures or unplanned downtimes due to maintenance of capsules (Kulińska \& Rut, 2014).

The existing solutions, which are already applied in existing pipelines intended for transportation of gas or crude oil (Kulińska \& Rut, 2014), could be used by designing maintenance solutions for underground transport of goods and raw materials (certainly they will have to be modified and/or adopted for the needs of the pipelines).

Modern storage facilities seem to be an important element. Both in Poland as well as throughout Europe, there are many objects, which meet the highest requirements. They can also be the key factors by developing the underground pipeline network (Kulińska \& Rut, 2014).

Pipelines will be located mainly in the public space, which should enable simple and fast planning. The layout of the pipeline network must take into account the existing underground infrastructure including gas and water pipelines as well as subway tunnels. Scientists work on an optimal method of building underground corridors, which could be competitive, fast, and environmentally friendly and above all expanded fast and quickly.

\section{Development of the Capsule Construction for Materials}

Transportation in such a system would be affected in capsules especially designed for this purpose. Their sizes and transport capacities are different in different projects. The most reasonable seems to be designing capsules for transportation of two euro pallets (Figure 2), as they are used for most freight within Europe. The capsule pipeline diameter in such a case would be two meters.
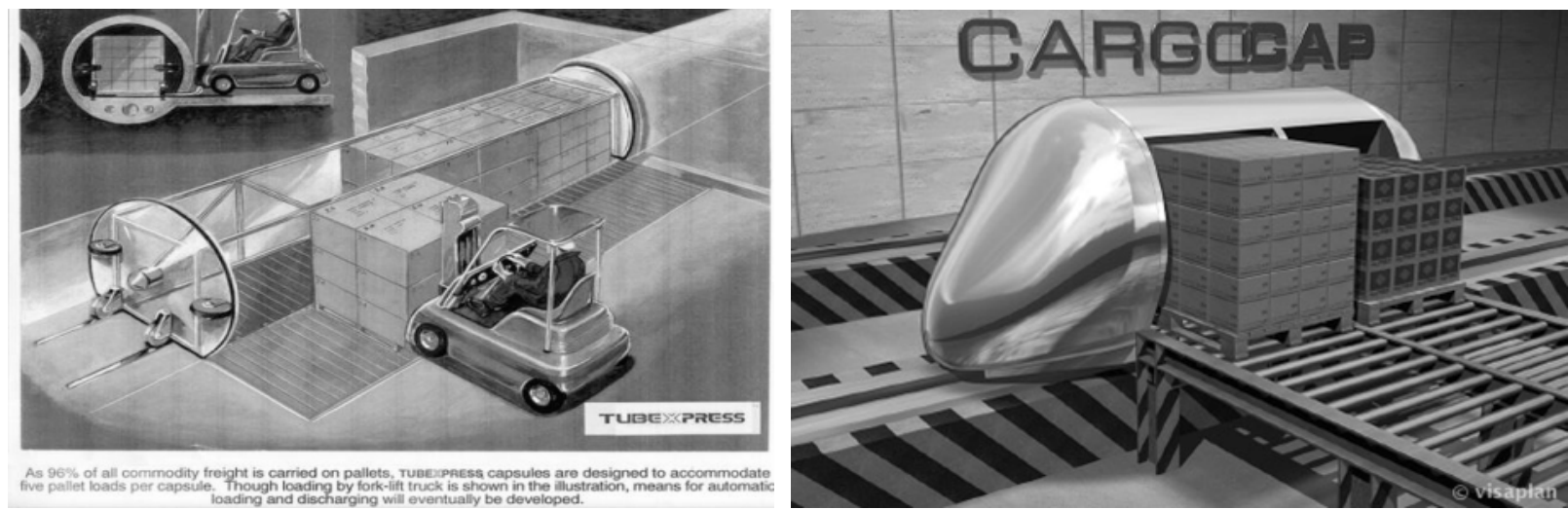

Figure 2. An example of a capsule for underground transport of two pallets. Source: Hodson and Taylor (2014) and Hölscher (2012).

Euro pallet is a standardized cargo volume, which would perform well in practice. The use of the euro pallet would enable easy implementation of the transport of this type within the frames of the existing logistics chains. Due to the load of only two euro pallets, loading and distribution could be carried out very flexibly. If there is a need of transporting more goods, more capsules can be used (Figure 3). The flexibility and fully automated loading and unloading process will guarantee competitiveness of this solution. 
Since pipeline transportation is independent from other types of transport, traffic routes, weather conditions, and congestions, it is possible to determine a fixed speed and constant streams of supplies. This results directly in shortening transport times compared to trucks in congested urban areas.

The speed estimated for such transportation in the Cargo Cap project is about $22 \mathrm{mph}$ that is $40 \mathrm{~km} / \mathrm{h}$. The destination location for sending/receiving stations can be a factory, a logistics center, or a hypermarket.

This is a point-to-point type of transportation: from a warehouse to a store, from a distribution center to a logistics center or vice versa; the aim is to deliver goods to the destination point. Underground transportation of bulk goods is a way to optimize the e-commerce and logistics processes.

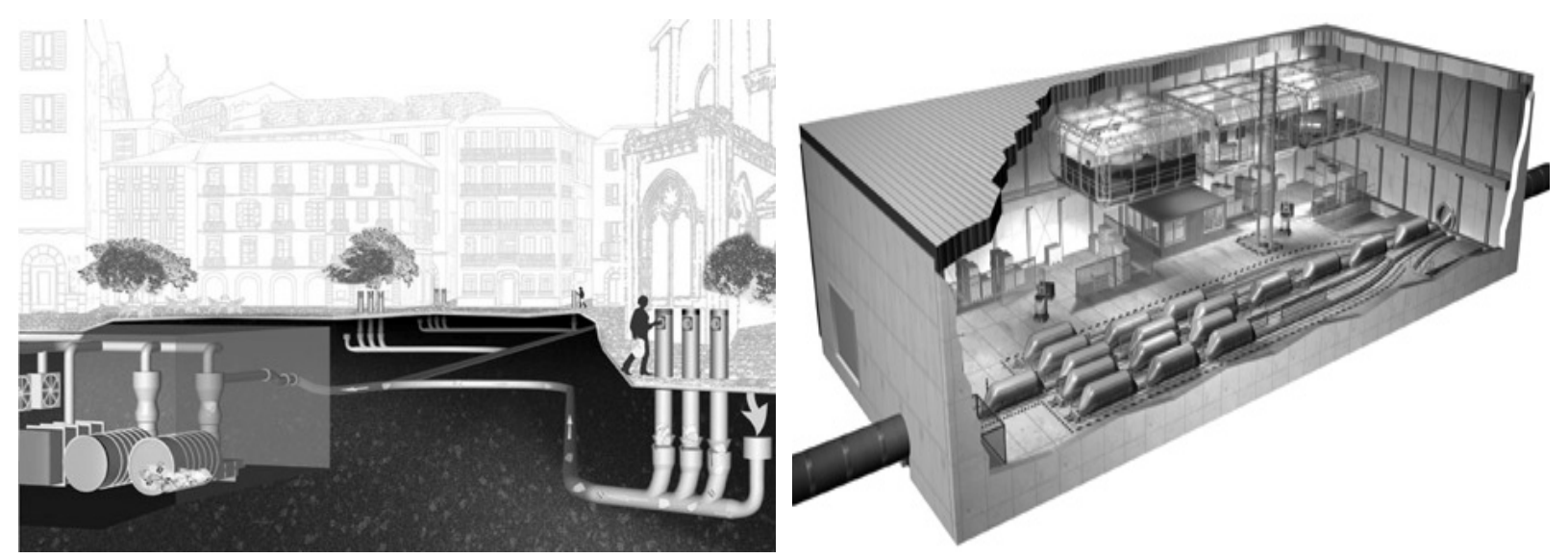

Figure 3. The interior of a reloading/loading/unloading station. Source: Hodson and Taylor (2014) and Hölscher (2012).

A supplier and a buyer shall be informed on the precise current location of sent/ordered goods.

In case of increased demand for transport services, the capsules can be sent in columns. This requires a proper control over the movement of the capsules for securing safe distance between them (the safe distance is estimated for about two meters). Moreover, the possibility of such transfer has to be taken into account, while designing the pipeline structure - control at junctions so as that the whole column could move without necessity of the speed reduction. The travel direction - the destination station — shall be selected in the control system of a capsule in the on-board capsule computer. It is the only way to secure constant/expected transport stream.

As soon as the goods loaded on the pallets reach their destination, the capsules will be automatically unloaded. Further transport will be carried out using vertical and horizontal conveyors. Vertical conveyors are used to transport pallets, which are unloaded underground, to the surface of the terrain. Unloading stations themselves can be planned and constructed in accordance with customer needs. An example of a receiving/sending station is shown in the Figure 4.

There are several solutions for the concept of the unloading station (Figure 5):

- an unloading station on the surface in the area, where the capsules are transported through pipelines to the surface, possibly with a connection to a high storage warehouse;

- an underground unloading station: Deliveries are transported from the unloading station to the recipient using vertical conveyors;

- a delivery to industrial subway or business center through successive underground distribution stages using normal distribution conveyors. 


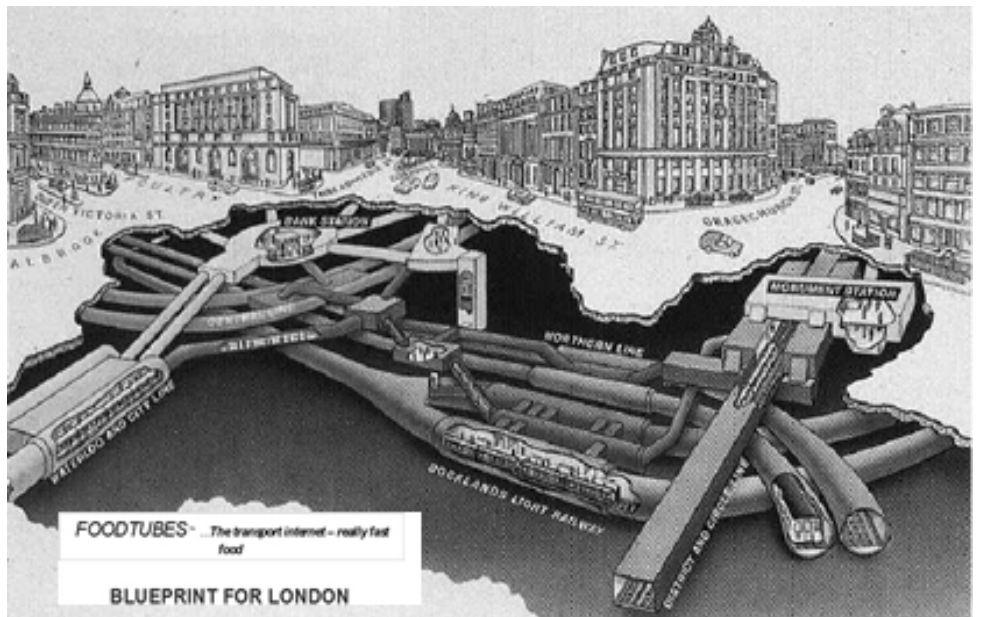

Figure 4. An example for a sending/receiving station of the underground transport system. Source: Lasar (2010) and Hodson and Taylor (2014).

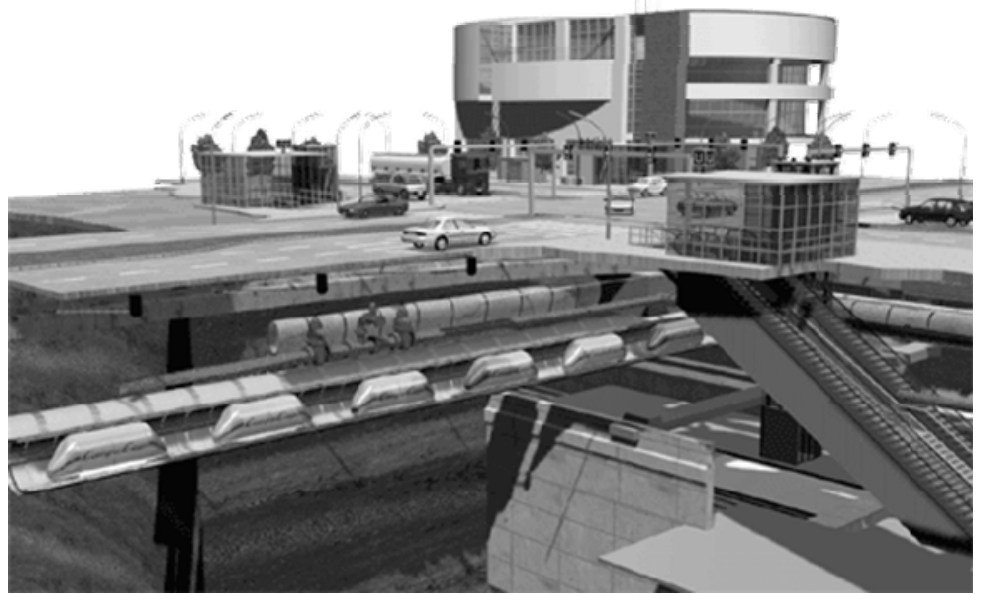

Figure 5. An example for a sending/receiving station of the underground transport system. Source: Hölscher (2012).

\section{Technical Problems}

It is assumed that the capsules will be designed aerodynamically with a load capacity of two pallets. They will have wheels working as bearings and side rolls keeping a capsule on its track (Figure 6). Electric wheel is driven by three-phase asynchronous motors supplied by frequency converters.
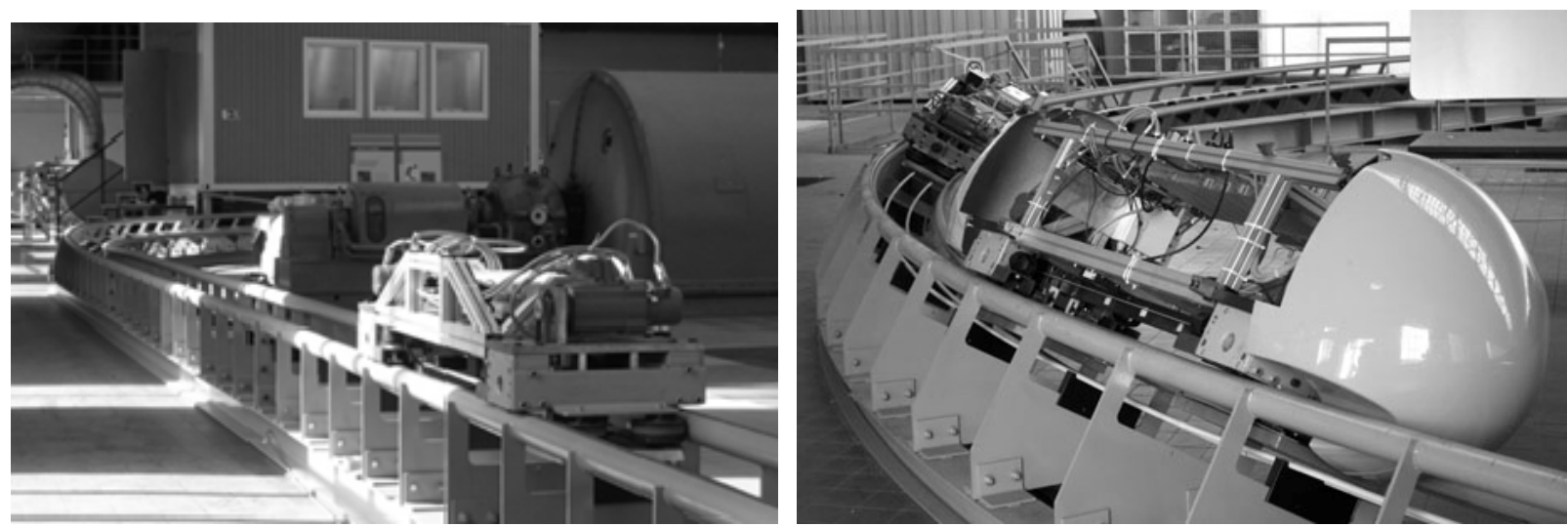

Figure 6. A prototype of a capsule chassis. Source: Hölscher (2012). 
This concept means a solid design, low power consumption, low initial costs, low number of defects, and less maintenance (Hohaus, 2009). Furthermore, the selected drive concept shall provide optimal traction combined with high security.

\section{Cross-section of the Pipeline and Construction of Pipeline Routes}

The pipeline infrastructure shall be built underground, leaving unaltered functioning of the ground traffic. It is possible with the use of the jacking method by tunneling (Figure 7). Trenchless methods of tunneling for underground pipelines are intended for use in towns, where they enable building underground network infrastructure, including sewage pipelines, without interfering with traffic. This allows for avoiding losses arising from accidents, stress, and property damages, which result from street works.

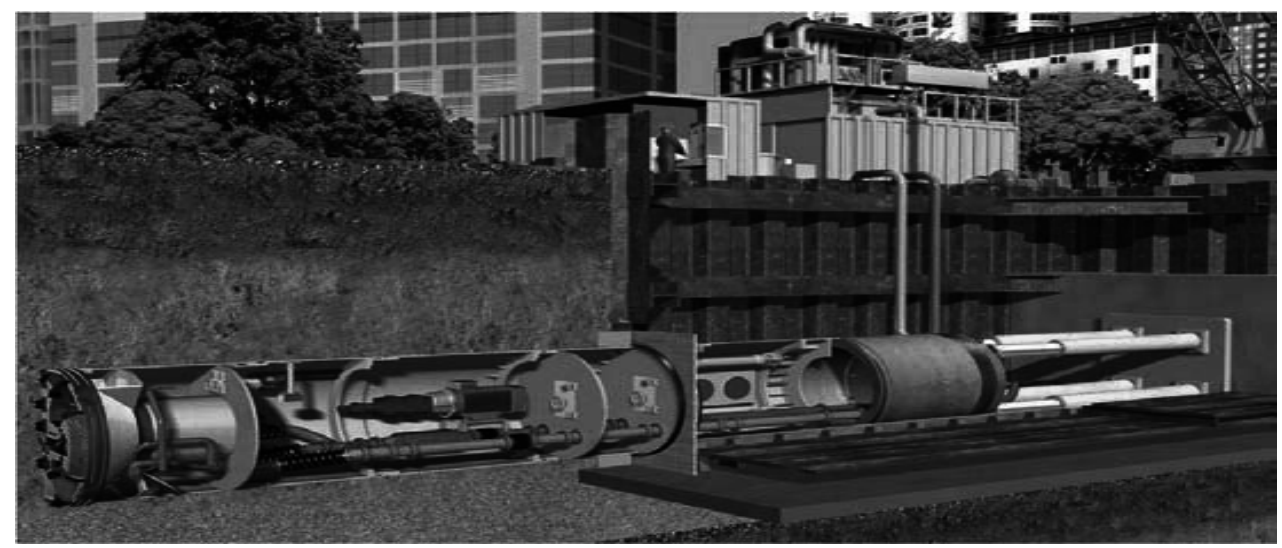

Figure 7. Drilling pipeline corridors. Source: Hölscher (2012).

One of several methods of trenchless tunneling can be selected depending on the geological structure of a terrain:

- pneumatic jacking with a punch, the so-called mole (Impast Moling): This method consists in guiding a pneumatic punch through the ground at a specified distance;

- pneumatic insertion of steel pipes (Impast Ramming): This method consists in hammering steel pipes into the ground using a punch located in the initial excavation, in a special bed, which is also called cradle or carriage;

- guided boring and directional drilling: Pipelines are built into the ground using drilling devices equipped with hydraulic motors, which produce torques and axial forces necessary for pressing, turning, and pulling drilling lines;

- pipe jacking: The technology of pipe jacking consists in inserting steel casing pipes into the ground by means of hydraulic cylinders;

- microtuneling: It consists in pneumatic inserting of line pipes, which follow a device located at their front, which is called a head and drills the tunnel (Zwierzchowska, 2006).

While choosing a trenchless method, one should take into account:

- technical specifications of the methods: The maximum length of a pipeline is built at one time, the maximum and minimum values of the diameter;

- characteristics of the ground, in which the pipeline is supposed to be built: Whether it is possible to thicken the ground, if it is necessary to remove dredged material, ground stability;

- groundwater level: If the given method can be applied below the groundwater level, then how deep is below the water table; 
- the material used for the pipeline: The choice of the material depends on the jacking strength, sometimes there is a need of integrating casing pipes;

- the desired degree of accuracy of building the pipeline in: Values of deviations of the trajectory of the pipeline built compared to the planned one depend on the control system and the process control system;

- the minimum thickness of the ground above the constructed pipeline: It depends on the diameter of the hole to be made, the presence of dynamic forces, while building in, the way of removing dredged material (use of scrubbers will usually result in disturbing the ground) (Zwierzchowska, 2006).

\section{Control}

Nowadays, it is more and more difficult to imagine correct functioning of even a small business without software recording transport events, supporting planning deliveries of products to customers and reliable supply of raw materials, controlling costs and the use of means of transport, supporting dispatchers or forwarders and automating their day-to-day duties. It would be also very useful to take into account the process of planning, monitoring, and tracking. An essential element, which has to be taken into account, is undisturbed actual flow of information. The software, which would be responsible for the information flow, would have to take into account effective cooperation amongst terminals (Zwierzchowska, 2006).

For tracking or monitoring a capsule transporting products and raw materials, the existing solutions can be applied (certainly after their adaptation to the needs of the system) such as the RFID system, technical security systems including optoelectronic (laser) systems, alarm systems, or CCTV systems.

All management of tracking pipeline transport and moving capsules/containers would have to be affected by using integrated advanced information systems, which could use artificial intelligence/a neural network. As regards the monitoring of products and raw materials, if there is such a need or necessity, it would be possible to use computer image analysis, by means of which hazardous materials could be identified (the ones threatening pipelines) (Zwierzchowska, 2006).

\section{Pipeline Reliability}

The basis for functioning of the underground transport of materials is its safety. It is for this purpose that capsules will be equipped with monitoring of the key components, two independent braking devices, and several engines so that a capsule will be able to get to the nearest station in case of any failure. Furthermore, the capsule fronts will be equipped with a safety system to stop capsules while detecting an obstacle.

It is very important for the safety to design pipelines and capsules in such a way that all the elements, which will be consumed in the course of time and have to be replaced, are mounted on a capsule and not in the pipelines. It will provide the ease and speed of exchange of such element and reduce costs.

The project teams are open to any innovation. Novelties in drives, constructions, drivers, construction materials for pipelines, capsules and their components are constantly followed. All innovations in monitoring and controlling capsules, which ensure safety of transport, both of a capsule itself and transported goods, are particularly important. In addition, it can be used to monitor goods ordered by a customer at any time.

Such a complex structure requires ongoing monitoring and continuous exchange of information. This is possible by using sensors and interfaces dedicated to specific tasks and a minimum of two communication systems for communication amongst stations.

\section{Legal Problems}

The legal problems associated with the construction and functioning of transport pipelines have to be 
solved too. The starting point for legal issues is the legal classification of the underground pipeline transportation. The legal standards are dependent on the classification, i.e., if pipeline transport will be ruled by public traffic or public supply regulations. There is a concept of perceiving pipelines networks transporting goods as supply centers, i.e. units serving the social welfare. There is no law in force addressing pipeline transportation. However, it can be talked about the legislation concerning the transport of hazardous materials.

Transportation of hazardous products falls within the provisions under international agreements. In this case, the ADR ( $L^{\prime}$ Accord européen relatif au transport international des marchandises Dangereuses par Route) agreement is crucial (the European agreement concerning the international carriage of dangerous goods by road), which was drawn up in Geneva on September 30, 1957 and amended several times since then. This agreement is used above all for increasing the level of transport safety of hazardous goods and materials and for harmonization and improvement of national and international legislation in this field (Polish Journal of Laws, 2011).

The planned solution in the form of pipelines must contain the standards mentioned above.

The ADR agreement consists of the provisions of the base agreement (introductory provisions) and of the two annexes (A and B). The annexes are divided into nine thematic sections, whereby they provide detailed recommendations for each of the stages of the ADR transport (ADR classification, packaging, loading and unloading, transportation).

\section{Project Risk Analysis}

Quality and reliability are necessary for economic efficiency and effectiveness in the implementation of logistics processes. Delays in deliveries have far-reaching consequences. This is particularly evident in case of highly distributed supply chains, which are connected with a classical traffic system. In this case, the use of pipeline transportation may improve transport processes and reduce the number of warehouses reducing significantly costs.

The economic benefits arising from the specialization of individual companies and outsourcing production units may occur only if the flow of goods is safe in the process of creating value added (B2B). At the same time, the flexibility concerning the response to inquiries of customers becomes a more and more crucial factor for the success in increasing turnovers (B2C).

Due to its independence from other transport systems, the pipeline system may deliver goods on time. It applies not only to wholesale transport quantities, also smaller lots may be transported at competitive prices. For retail customers as well as consumers, the collection, automated ordering systems, subcontracting and finally recycling packaging materials may be offered as a result of combining orders in designated areas.

There is no doubt that a project of underground transportation will be created. The result will be different for various projects - as a computer simulation or as a prototype, if the appropriate financial resources are available.

It will be possible to talk about success of a project, if it is commercialized.

\section{Conclusions}

Pipeline transportation may support effectively economic development and increase competitiveness of the business location causing far-reaching benefits for environment and safety. It is used for transportation of liquids and gases to the greatest extent in the United States, Russia, and Canada. Therefore, there should be a possibility of transporting solid and bulk goods in this way. 
The underground transport is an intelligent, innovative, and computer-controlled transport system for the new millennium: environmentally friendly, fast, flexible, and competitive. The use of this way of transportation will increase the probability of arriving products, raw materials, goods etc. on time at planned dates. They will not have to be transported by tracks, which will contribute to avoiding traffic jams, red lights, and road accidents.

In crowded urban areas, the labor market and the number of potential consumers are very large. Effective road transport systems corresponding to supply chains and improving operations of holding companies, etc. are bottleneck factors of many projects.

In many places of the world, the overcrowded roads can be expanded only by investing very high amounts of money and only if it is spatially and technically possible. The existing undeveloped areas rarely meet economic requirements in respect of their size or road transport connections.

The underground pipeline transport of solid and bulk goods may reduce these problems due to its underground construction, working mode, and efficiency. Production facilities may be physically connected with another and practically consolidated in this way. By connecting with a system of pipelines, the receiving capacity in freight transport clearly increases. Reduction of specific defects, such as congestions, causes that the development of the densely populated urban areas is again a priority issue and increases the location attractiveness.

Since the underground pipeline transport is designed for land transport in developed areas as well as for exports, benefits arising from it are not reduced by the increase in transit traffic, as it could be the case, for example, when a highway is expanded.

\section{Reference}

Colliers International. (2012) To 2020 year Poland as logistics center of Europe (Do 2020 r. Polska centrum logistycznym Europy). $\quad$ Retrieved from http://spedycje.pl/logistyka/centra_logistyczne/28612/do_2020_r_polska_centrum_logistycznym_europy.html

Hodson, N., \& Taylor, F. (2014). Croydon. Retrieved from https://www.youtube.com/watch?v=x0SgwSg3Q9E

Hohaus, L. (2009). Entwicklung einer Verzweigungsvorrichtung für das System Cargo Cap-Simulationsgestützte Ermittlung von Betriebslasten (Ruhr-Universität Bochum, Bochum).

Hölscher, H. (2012). Cargo Cap-Optimale Koordinierung der Fahrbewegungen autonomer Fahrzeuge im lokalen Umfeld von Verzweigungen und Zusammenführungen (Ruhr-Universität Bochum, Bochum).

Hölzel, A. (2014). Staubilanz 2013: 830,000 Kilometer Stillstand in einem Jahr. Retrieved from https://presse.adac.de/meldungen/touristik/staubilanz-2013-830000-kilometer-stillstand-in-einem-jahr.html

Kulińska, E., \& Rut, J. (2014). Developing the concept of WP2. problem areas of R\&D pipelines (Opracowanie koncepcji WP2. Obszary problemów badawczo-rozwojowych transportu rurociagowego, unpublished materials to Horizont 2020, Praga).

Kulińska, E., Rut, J., \& Partyka, P. (2014). Szansa ograniczenia zjawiska kongestii z wykorzystaniem elastycznych pasów ruchu (Hence reducing the chance of congestion using flexible lanes). Logistyka, 2, 26-34.

Lasar, M. (2010). Can we transport food like Internet data? Foodtubes says yes. Retrieved from http://arstechnica.com/tech-policy/2010/12/want-fries-with-those-packets-introducing-foodtubes/

McKinnon, A., Button, K., \& Nijkamp, P. (2003). Classics in transport analysis: Transport logistics. Cheltenham: Edward Elgar Publishing.

Official Journal of the European Union. (2014). Commission implementing regulation (EU) No 228/2014 of 10 March 2014, amending regulation (EC) No 601/2006, implementing regulation (EC) No 184/2005 of the European Parliament and of the Council on statistics concerning balance of payments, international trade in services and foreign direct investment, as regards the format and the procedure for the transmission of data. Retrieved from http://eur-lex.europa.eu 
Polish Journal of Laws. (2011). Restructured ADR agreement effective from January 1, 2003: European agreement concerning the international carriage of dangerous goods by road (Zrestrukturyzowana Umowa ADR obowiązująca od dnia 1 stycznia 2003 r: Umowa europejska dotycząca międzynarodowego przewozu drogowego towarów niebezpiecznych). Polish Journal of Laws, 1(110), 641-641.

Roe, M. (1998). The use of pipelines for the urban distribution of goods. Transport Policy, 5(2), 61-72.

Wappa, P., \& Halicka, K. (2011). The meaning and source of transport congestion on the example of the urban agglomeration of Bialystok (Znaczenie i źródło kongestii transportowej na przykładzie białostockiej aglomeracji miejskiej, Ekonomia i Zarządzanie). Economics and Management, 3(4), 63-64.

Zwierzchowska, A. (2006). Technologie bezwykopowej budowy sieci gazowych, wodociagowych i kanalizacyjnych (Trenchless technology construction of gas networks, water supply and sewerage). Kielce: Kielce University of Technology Publishing House (Wyd. Politechniki Świetokrzyskiej). 